\title{
PENGARUH EKSTRAK BIJI COKELAT (THEOBROMA CACAO L) TERHADAP KADAR MALONDIALDEHID (MDA) TIKUS PUTIH JANTAN (RATTUS NORVEGICUS STRAIN WISTAR) DENGAN INDUKSI HIPERKOLESTEROL
}

\author{
Faiz Zulkifli ${ }^{1}$, Sulistyo Mulyo Agustini ${ }^{2}$, Annisa' Hasanah ${ }^{3}$ \\ Fakultas Kedokteran, Universitas Muhammadiyah Malang \\ J1. Bendungan Sutami No. 188 A Malang, 65145
}

Email : faizzulkifli10@gmail.com

\begin{abstract}
ABSTRAK
Hiperkolesterol menyebabkan peningkatan peroksidasi lipid dan menghasilkan Malondialdehid (MDA) sebagai indikator stres oksidatif. Ekstrak biji cokelat mengandung flavonoid sebagai antioksidan untuk menurunankan kadar MDA plasma tikus. Tujuan penelitian ini untuk mengetahui pengaruh ekstrak biji cokelat (Theobroma Cacao L) terhadap kadar (MDA) tikus putih jantan (Rattus novergicus strain wistar) dengan induksi hiperkolesterol. Metode yang digunakan Penelitian ini true experimental dengan menggunaka post test only control group design. menggunakan 25 ekor tikus putih jantan, dibagi menjadi 5 kelompok (kontrol negatif, kontrol positif, diberi ekstrak biji cokelat 1,8 mg, 3,6 mg dan 5,4 mg p.o selama 37 hari) dengan Parameter MDA plasma tikus metode spektofometri dan dianalisis menggunakan uji ANOVA, Post Hoc Benferoni, Korelasi serta Regresi. Hasil Uji ANOVA menghasilkan pengaruh yang signifikan dengan Sig $=0,000<\mathrm{p}(0,05)$. Uji Post hoc Benferoni menunjukkan pengaruh yang berbeda diantara masing-masing kelompok perlakukan kecuali antara perlakuan 1 dan perlakuan 2 yang tidak berbeda signifikan. Hasil uji korelasi menunjukkan pearson correlation $=-0,961$ yang berarti hubungan korelasi sangat kuat. Hasil uji regresi menunjukkan pengaruh yang signifikan $\left(\mathrm{R}^{2}=0,919\right.$; $\operatorname{Sig} 0,000<\mathrm{p}(0,05)$ ). Kesimpulan penelitian ini Ekstrak biji cokelat dapat menurunkan kadar MDA tikus putih jantan dengan induksi hiperkolesterol.
\end{abstract}

Kata kunci : Ekstrak biji cokelat, hiperkolesterol, MDA.

\begin{abstract}
Hypercholesterol causes the increase of lipid peroxidation and produces Malondialdehyde (MDA) as an indicator of oxidative stress. The extract of Cocoa seed extract contains flavonoid as antioxidant to decrease of MDA level of rats' plasma. The purpose of the research To determine the effect of cocoa seed extract (Theobroma Cacao L) on the levels of Malondialdebyde (MDA) in male white rats (Rattus novergicus strain wistar) through Hypercholesterol induction. The true experimental research used the post-test only control group design. The subjects of the research 25 male white rats, divided into 5 groups (negative control, positive control, and those given 1.8 $\mathrm{mg}, 3.6 \mathrm{mg}$, and $5.4 \mathrm{mg}$ p.o within 37 days) with parameters are the MDA of rats' plasma method by spectrophotometry and analyzed by ANOVA test, Post Hoc Benferoni, Correlation, and Regression. The Result of ANOVA test was resulted the significant effect with Sig $=0,000<p(0,05)$. The post-hoc Benferoni test showed different effects between each group, except P1 and P2 which were not significant. The result of the correlation test showed pearson correlation $=-0.961$, which indicated a very strong correlation relationship and showed as the higher dosage of the extract, caused lower level of $M D A$. Regression test showed a significant effect $\left(\mathrm{R}^{2}=0,919 ;\right.$ Sig 0,000 < $p(0,05))$. Conclusion of this study of Cocoa seed extract could decrease the MDA levels of male white rats through bypercholesterol induction.
\end{abstract}

Keywords : Cocoa seed extract, bypercholesterol, $M D A$ 


\section{LATAR BELAKANG}

Hiperkolesterolemia merupakan salah satu faktor risiko penyakit kardiovaskuler yang menjadi penyebab utama kematian dan kesakitan di seluruh dunia (Bantas, Krisnawaty, dkek. 2012) . Berdasarkan laporan World Health Organization (WHO) pada tahun 2002, Mencatat sebanyak 4,4 juta kematian akibat hiperkolesterol atau sebesar 7,9\% dari jumlah total kematian di usia muda. Menurut Riset Kesehatan Dasar (Riskesdas) tahun 2013, prevalensi hiperkolesterolemia di Indonesia pada usia $>15$ tahun sebesar 35,9\%.

Hiperkolesterol menyebabkan peningkatan peroksidasi lipid sehingga terjadi kerusakan pada sel yang di tandai dengan Lipid Perioxidation Potential (LPP) di dalam jaringan. Malondialdehide (MDA) merupakan Produk yang dihasilkan akibat peroksidasi lipid. Kadar MDA yang tinggi menunjukkan bahwa sel mengalami stress oksidatif yang disebabkan produksi radikal bebas berlebih, tanpa diimbangi dengan antioksidan sehingga mengakibatkan kerusakan jaringan.

Biji Cokelat sendiri memiliki sifat antioksidan karena dalam biji cokelat mengandung senyawa flavonoid. Kandungan flavonoid dalam biji cokelat sekitar 12-18\%. Dalam mekanisme kerjanya, flavonoid yang merupakan antioksidan endogen akan menghambat reaksi radikal bebas dalam tubuh dan meningkatkan antioksidan endogen. Senyawa polifenol yang paling menarik dari cokelat adalah golongan flavanols. Flavanols merupakan sub kelas dari flavonoid yang terbagi menjadi monomer dan dimer. Kandungan flavanols yang terbanyak di kandung dalam biji cokelat golongan cathechin dan epichatechin sekitar 35\% dan berperan sebagai zat antioksidan.

Indonesia merupakan salah satu negara pembudidaya tanaman kakao paling luas di dunia dan termasuk negara penghasil kakao terbesar ketiga setelah Pantai Gading dan Ghana, yang nilai produksinya mencapai 1.315 .800 ton/thn. Dalam kurun waktu 5 tahun terakhir dari 2005 sampai 2010, perkembangan luas areal perkebunan kakao meningkat secara pesat dengan tingkat pertumbuhan rata-rata $8 \% /$ thn dan saat ini mencapai 1.462 .000 ha. Hampir $90 \%$ dari luasan tersebut merupakan perkebunan rakyat yang banyak berada di Jawa khususnya Jawa Timur dan Sumatera. Berdasarkan latar belakang tersebut, maka penelitian ini bermaksud untuk membuktikan pengaruh ekstrak biji cokelat terhadap kadar malondialdebid tikus putih jantan (Rattus Norvegicus strai wistar) induksi hiperkolesterol.

\section{TINJAUAN PUSTAKA}

Hiperkolesterolemia merupakan gangguan metabolisme yang terjadi secara primer atau sekunder akibat berbagai penyakit yang dapat berkontribusi terhadap berbagai jenis penyakit.

Hiperkolesterolemia berhubungan erat dengan hiperlipidemia dan hiperlipoproteinemia. Hiperkolesterolemia dapat terjadi akibat kelainan kadar lipoprotein dalam darah yang dalam jangka panjang mempercepat kejadian arteriosklerosis. (Bantas, Krisnawaty, dkek. 2012)

Kolesterol memainkan peran utama dalam kesehatan jantung manusia. Kolesterol bisa baik dan buruk. High-density lipoprotein (HDL) adalah kolesterol baik dan low-density lipoprotein (LDL) adalah kolesterol jahat. kolesterol tinggi dalam serum merupakan faktor risiko utama untuk penyakit jantung manusia seperti penyakit jantung koroner dan stroke - nomor satu Amerika pembunuh.

Kolesterol merupakan substansi lipid yang terdapat pada membrane sel dan berperan dalam berabagai biosintesis sterol : asam empedu, hormone adrenokortikal, androgen dan esterogen. Banyak penelitian membuktikan bahwa kenaikan kolesterol plasma merupakan faktor resiko penting berkembangnya Penyakit Jantung Koroner (PJK). Kadar kolesterol total $>6,5 \mathrm{mmol} / \mathrm{L}$ melipat gandakan risiko PJK mematikan dan jika $>7,8$ mmol/L meningkatkan resiko sampai empat kali lipat. Penurunan kadar kolesterol total sebesar 20\% akan menurunkan resiko koroner sebesar 10\%.

Metabolism lipoprotein dari kolesterol dapat dibagi atas 3 jalur yaitu jalur metabolism eksogen, jalur metabolism endogen dan jalur reverse cholesterol transport. Kedua jalur pertama berhubungan dengan metabolism kolestero-LDL dan TG, sedangkan jalur reverse cholesterol transport khusus mengenai metabolism kolesterol HDL.

Pertama yaitu jalur eksogen, Ada 2 sumber kolesterol yaitu berasal dari diet dan kolesterol dari hati yang diekskresi bersama empedu ke usus halus, Baik lemak di usus halus yang berasal dari makanan maupun yang berasal dari hati disebut lemak eksogen. TG dan kolesterol dalam usus halus akan di serap ke dalam enterosit mukosa usus halus. TG akan diserap sebagai asam lemak bebas sedang 
kolesterol sebagai kolesterol dicampur dengan lesitin, lysolecithin, dan garam empedu menjadi larut.

Didalam usus halus asam lemak akan bebas akan diubah lagi menjadi TG, sedangkan kolesterol akan mengalami esterifikasi menjadi kolesterol ester dan keduanya bersama dengan fospolipid dan apolipoprotein yang dikenal dengan kilomikron. Kilomikron ini masuk ke saluran limfe dan akhirnya melalui duktus torasikus akan masuk ke aliran darah. TG dalam kilomikron akan mengalami hidrolisis oleh enzim lipoprotein lipase yang berasal dari endotel menjadi asam lemak bebas (free faty acid $(\mathrm{FFA})=$ non-esterified fatty acid (NEFA).

Asam lemak bebas dapat di simpan sebagai TG kembali di jaringan lemak (adiposa), tetapi bila terdapat dalam jumlah yang banyak sebagian akan diambil oleh hati menjadi bahan untuk pembentukan TG hati. Kilomikron yang sudah kehilangan sebagian besar trigliserid akan menjadi kilomikron remnant yang mengandung kolesterol ester dan akan dibawa ke hati.

Kedua adalah Jalur Metabolisme Endogen Trigliserid dan kolesterol yang disintesis dari hati dan disekresi kedalam sirkulasi sebagai lipoprotein VLDL. Apolipoprotein yang terkandung kedalam VLDL adalah Apolipoprotein B100. Dalam sirkulasi, trigliserid di VLDL akan mengalami hidrolisis oleh enzim Lipoprotein lipase (LPL), dan VLDL berubah menjadi IDL (Intermediete Density Lipoprotein) yang akan diambil oleh hati atau juga akan mengalami hidrolisis dan berubah menjadi LDL.

Ketiga dengan Jalur Reverse Cholesterol Transport, HDL dilepaskan sebagai partikel kecil miskin kolesterol yang mengandung apolipoprotein (apo) A, C, E; dan Apo A1 disebut HDL nascent. HDL nascent berasal dari usus halus dan hati, akan mendekati makrofag untuk mengambil kolesterol yang tersimpan di makrofag. Setelah mengambil kolesterol bebas dari sel makrofag, kolesterol bebas akan diesterifikasi menjadi kolesterol ester oleh enzim lecithin cholesterol acyltransferase (LCAT).

Selanjutnya sebagian kolesterol ester yang di bawa oleh HDL akan mengambil 2 jalur. Jalur pertama ialah ke hati dan jalur kedua adalah kolesterol ester dalam HDL akan dipertukarkan dengan trigliserid dari VLDL dan IDL dengan bantuan cholesterol ester transfer protein (CETP). Dengan demikian fungsi HDL sebagai penyerap kolesterol dari makrofag mempunyai dua jalur yaitu langsung ke hati dan jalur tidak langsung melalui VLDL dan
Intermediet Density Lipoprotein (IDL) untuk membawa kolesterol kembali ke hati.

Banyaknya LDL yang di keluarkan akan terjadi penumpukan LDL berlebih didalam sirkulasi yang berakibat mudahnya molekul LDL teroksidasi oleh logam transisional seperti iron $(\mathrm{Fe})$ atau Cooper $(\mathrm{Cu})$ yang banyak terdapat dalam tubuh. LDL yang teroksidasiakan terbentuk ox-LDL. Ox-LDL ini menyebabkan disfungsi endotel dikarenakan aktivasi lecithin-like ox-LDL reseptor (LOX-1). LOX-1 merupakan reseptor ox-LDL yang terdapat di sel endotel kapiler. Ketika ox-LDL terikat dengan LOX-1 akan menginduksi terbentuknya Reactive oxygen species (ROS).

ROS kemudian akan berikatan dengan poly unsaturated fatty acid (PUFA) yang terdapat di membran sel. Ikatan ini yang akan membentuk perioksidasi lipid melalui mekanisme rekasi berantai yang kemudian akan terbentuk senyawa aldehid dan terbentuk malondialdebid (MDA) yang sebagai biomarker terjadinya stress oksidatif. ROS juga memicu meningkatnya Nitrit oxide synthese yang akan menghasilkan NO yang tinggi yang akan menyebabkan oksidasi LDL. Selain sebagai biomarker, MDA tersusun atas molekul aldehid yang sangat beracun. Interaksinya dengan DNA maupun protein akan menyebabkan terjadinya mutagenik dan juga akan terjadinya aterosklerosis ${ }^{[4]}$. Saat ini produk kakao banyak mendapat perhatian karena mempunyai kemampuan sebagai antioksidan. Polifenol golongan flavonoid terutama katekin dan epikatekin adalah komponen utama dalam produk kakao yang berperan sebagai antioksidan. Polifenol kakao mempunyai manfaat yaitu dapat mencegah terbentuknya radikal bebas, dapat melindungi oksidasi LDL darah, berpengaruh terhadap antimutagenik, dan dapat menghambat tumor. Hasil penelitian berbeda dengan literatur, yaitu dalam penelitian sebelumnya, dengan bubuk kakao yang sama menunjukkan total fenol sebesar $935.000 \mathrm{mg} / \mathrm{kg}$. Polifenol dalam biji kakao dapat berkontribusi sekitar 12\% $-18 \%$ dari berat kering dengan katekin, antosianin, dan proantosianidins merupakan sekitar 37\%, 4\% dan $58 \%$ polifenol biji kakao masing-masing.

Senyawa polifenol yang paling menarik dari cokelat adalah flavanols. Flavanols merupakan sub kelas dari flavonoid, dan flavonoid merupakan turunan kelas dari polifenol. Flavanols dapat dibagi lebih lanjut menjadi monomer (epicatechin dan cathechin), dimer (yang paling umum dalam cokelat 
B2 dan B5, yang terbuat dari dua unit epicathechin dengan link yang berbeda), atau polimer dari kombinasi monomer ini. (Andujar, M. 2012)

Ekstrak biji cokelat mengandung substansi polifenol dan zat antioksidan flavonoid yang tinggi. Flavonoid memiliki efek antioksidan intraseluler atau ekstraseluler. Radical scavenging adalah mekanisme pertahanan radikal bebas yang bekerja untuk menangkap radikal bebas melalui inisiasi penghambatan reaksi berantai dan memotong propagasi reaksi radikal bebas. Selain Radical scavenging, flavonoid pada biji cokelat berperan sebagai chelation logam transisi yaitu mekanisme pertahanan radikal bebas yang ada reaksi dengan logam transisi yang penting dalam produksi zat radikal bebas seperti, tembaga, zat besi, zincum12.

Mekanisme kerja senyawa flavanoid yang lain terdapat dalam biji cokelat dalam menurunkan kolesterol darah diduga bekerja dengan cara penghambatan terhadap HMG-CoA Reduktase. Penghambatan terhadap HMGCoA Reduktase menyebabkan penurunan sintesis kolesterol dan meningkatkan jumlah reseptor LDL yang terdapat dalam membran sel hepar dan jaringan ekstrahepatik sehingga kadar kolesterol total turun, dengan penurunan kadar kolesterol maka LDL sebagai alat angkut lipid di dalam darah juga berkurang kadarnya.(Baskaran, Gunasekaran, et al. 2015)

\section{Metode penelitian}

Penelitian ini merupakan penelitian true experimental dengan menggunakan metode post test only control group design. Penelitian ini dilaksanakan selama kurang lebih 37 hari pada bulan Maret 2017 - April 2017 bertempat di Laboratorium Fakultas Kedokteran Universitas Muhammadiyah Malang. Populasi dalam penelitian ini adalah tikus putih jantan (Rattus novergicus strain wistar).

Sampel yang dilakukan penelitian ini menggunakan teknik simple random sampling dari populasi tikus putih (Rattus norvegicus) berjenis kelamin jantan, umur 2-3 bulan, berat badan 150-200 gram dengan kondisi sehat yang ditandai dengan gerakannya yang aktif. Sampel dikelompokkan menjadi 5 kelompok. Total sampel yang digunakan dalam penelitian ini adalah 25 ekor tikus putih jantan yang terbagi dalam satu kelompok kontrol positif, satu kelompok kontrol negative, dan tiga kelompok perlakuan dengan masing-masing kelompok terdiri dari 5 ekor tikus putih jantan.

Bahan induksi tinggi kolesterol berasal dari Kolesterol 2 gram (minyak kambing), kuning telur puyuh $1 \mathrm{gr}$, asam kolat 0,02 gram, aquades $2 \mathrm{ml}$, pakan BR-1 20 gram.

Dosis ekstrak biji cokelat yang diberikan yaitu 1,8 $\mathrm{mg} /$ hari, $3,6 \mathrm{mg} /$ hari dan $5,4 \mathrm{mg} /$ hari yang diberikan masing-masing pada kelompok 1,2,3 selama 30 hari. Biji cokelat yang digunakan merupakan spesies coklat lindak yang diambil dari kota blitar.

Proses adaptasi hewan coba dalam kandang selama 7 hari dengan tujuan agar tikus menyesuaikan diri terhadap lingkungan yang baru. Diet hiperkolesterol diberikan peroral dengan sonde selama 30 hari di mulai pada hari ke 8 . Pemberian ekstrak biji cokelat selama 30 hari melalui sonde modifikasi setiap jam 12.00-17.00 WIB.

Kontrol negatif hanya diberi pakan standar. Kontrol positif diberi pakan standar dan diet hiperkolesterol. Perlakuan 1 dosis ekstrak 1,8 mg, perlakuan 2 dosis 3,6 $\mathrm{mg}$ dan perlakuan 3 dosis 5,4 mg. Pada hari ke 37 tikus dibedah selanjutnya dilakukan pengukuran kadar MDA plasma tikus masing-masing kelompok. Hasil pengamatan akan dianalisis datanya menggunakan uji One Way Anova, uji post-hoc Bonferoni, uji korelasi dan uji Regresi linier.

\section{HASIL DAN PEMBAHASAN}

Hasil penelitian ini menunjukkan jumlah rerata kadar MDA pada $\mathrm{K}-=0,6119 \mathrm{nmol} / \mathrm{ml}$, $\mathrm{K}+=1,1078 \mathrm{nmol} / \mathrm{ml}, \mathrm{P} 1=0,9838 \mathrm{nmol} / \mathrm{ml}, \mathrm{P} 2$ $=0,9030 \mathrm{nmol} / \mathrm{ml}$, dan P3 $=0,7305 \mathrm{nmol} / \mathrm{ml}$. Pada uji One Way ANOVA menunjukkan bahwa nilai Sig $=0,00$ lebih kecil dari p (0.05) berarti terdapat perbedaan yang bermakna antara kadar MDA plasma kelompok perlakuan dengan kelompok kontrol positif.

Berdasarkan uji korelasi antara perlakuan (pemberian ekstrak biji cokelat dengan variasi dosis 1,8 mg, 3,6 mg, 5,4 mg) dengan kadar MDA plasma menunjukkan bahwa nilai sig (2-tailed) $=$ $0,000<\mathrm{P}(0,05)$ dengan kekuatan korelasi = 0,961 hal ini menunjukkan bahwa data berada dalam rentang 0,91-0,99 yang menunjukkan bahwa korelasi sangat kuat sekali dan berbanding terbalik. Hasil uji regresi linier menunjukkan $\mathrm{R}^{2}=0,923$ yang berarti penurunan kadar MDA plsama tikus jantan putih (Rattus norvegicus strain wistar) yang dipengaruhi oleh dosis pemberian ekstrak biji cokelat (Theobroma cacao L) adalah $92,3 \%$.

Berdaasarkan hasil penelitian dan analisis statistik didapatkan adanya pengaruh pemberian ekstrak biji cokelat (Theobroma Cacao L) terjadi 
penurunan MDA plasma tikus putih jantan. Sesuai dengan penelitian fridayanti, dkk (2015) pada tikus putih jantan bahwa ekstrak etanol kakao dapat menurunkan kadar MDA dan meningkatkan sel osteoblas tikus dengan model fraktur tulang.

Mekanisme kerja flavonoid dalam menurunkan kadar MDA sesuai penelitian yang dilaakukan sebelumnya oleh Heiss et al (2005) yang meneliti pemberian cacao kaya flavanol terhadap perbaikan disfungsi endotel pada perokok, menunjukkan bahwa pemberian flavanols 100-300 mg mampu mengembalikan disfungsi endotel.

Mekanisme kerja senyawa flavanoid yang lain dalam biji cokelat menurunkan kolesterol darah diduga bekerja dengan cara penghambatan terhadap HMG-CoA Reduktase. Penghambatan terhadap HMG CoA Reduktase menyebabkan penurunan sintesis kolesterol dan meningkatkan jumlah reseptor LDL yang terdapat dalam membran sel hepar dan jaringan ekstrahepatik sehingga kadar kolesterol total turun, dengan penurunan kadar kolesterol maka LDL sebagai alat angkut lipid di dalam darah juga berkurang kadarnya sehingga menurunkan pembentukan MDA.(Baskaran, Gunasekaran, et al. 2015)

Sebuah penelitian oleh Noori et al (2009) terhadap seekor tikus albino di dapatkan hasil bahwa antioksidan yang terdapat dalam cokelat dapat meningkatkan superoxide dismutase (SOD) yang merupakan antioksidan primer didalam tubuh sebesar 0,44 nmol/g. SOD adalah enzim antioksidan utama yang menyediakan langkah enzimatik pertama tubuh dalam sistem pertahanan terhadap stres oksidatif.

Selain dikenal memiliki banyak manfaat terhadap kesehatan, namun apabila intake flavonoid berlebihan akan menimbulkan efek toksik bahkan efek letal dari flavonoid. Penelitian ini menyebutkan bahwa intoksikasi akut pada tikus putih dapat terjadi apabila intake flavonoid mencapai dosis letal yang dapat menyebabkan kematian pada 50\% populasi hewan coba (LD50) $2 \mathrm{gr} / \mathrm{KgBB} / \mathrm{hr}$.

\section{KESIMPULAN DAN SARAN}

Kesimpulan dari penelitian ini adalah Pemberian ekstrak biji cokelat (Theobroma Cacao L) berpengaruh terhadap penurunan kadar MDA plasma tikus putih jantan hiperkolesterol dan Ekstrak biji cokelat dengan Dosis 1,8 mg, 3,6 mg dan 5,4 $\mathrm{mg}$ memiliki efek antioksidan yang berpengaruh terhadap penurunan kadar MDA plasma tikus.

Saran untuk penelitian lebih lanjut Perlu dilakukan penelitian dengan variasi dosis ekstrak biji cokelat (Theobroma Cacao L) dengan kadar yang lebih tinggi untuk mengetaahui dosis maksimal dalam menurunkan kadar MDA plasma tikus.

\section{DAFTAR PUSTAKA}

Andujar, M. 2012. Cocoa Polyphenols and Their Potential Benefits For Human Health. Article of Oxidative Medicine and Celluler Longevity. ID 906252.

Bantas, Krisnawaty, dkk. 2012. Risiko Hiperkolesterolemia pada Pekerja di Kawasan Industri. Jurnal Kesehatan Masyarakat Nasional. Vol. 6. No. 5.

Baskaran, Gunasekaran, et al. 2015. HMG-CoA reductase inbibitory activity and phytocomponent investigation of Basella alba leaf extract as a treatment for hypercholesterolemia. Drug Design, Development and Therapy Journal. 9: 509517.

Del Rio, Daniel, et al. 2005. A review of recent studies on malondialdehyde as toxic molecule and biological marker of oxidative stress. Nutrition, Metabolism \& Cardiovascular Diseases. No. 15. 316-328.

Deniel JR, Helen HH, 2012, Disorder of Lipoprotein Metabolism in Harrison's Principles of Internal Medicine Eighteenth Edition, The McGraw Hill, USA, pp 3145-3148.

Fridayanti, Febriana S, dkk. 2015. Hubungan antara Kadar Malondialdehyde (MDA) dengan Histopatologi Jaringan Tulang pada Tikus Wistar Jantan Model Fraktur Tulang. Journal of Agromedicine and Medical Sciences 1. Vol. 1 No. 1.

Grotto, Denise, et al. 2009. Low levels of methylmercury induce DNA damage in rats: protective effects of selenium. Arch Toxicol. 83: 249-254.

Heiss C, Kleinbongard P, Dejam A et al, 2005, Acute consumption of flavanolrich cocoa and the reversal of endothelial dysfunction in smokers, J Am Coll Cardiol 46(7):1276-1283.

Imes, Christopher. 2013. Low-Density Lipoprotein Cholesterol, Apolipoprotein B, and Risk of Coronary Heart Disease: From Familial Hyperlipidemia to Genomics. Biol Res Nurs. 15(3): 292-308.

Karmawati E, Mahmud Z, 2010, Budidaya dan Pasca Panen Kakao. Pusat Penelitian dan Pengembangan Perkebunan, Bogor.

Khan, Nasiruddin, et al. 2014. Cocoa Polyphenols and Inflammatory Markers of Cardiovascular Disease. Journal Nutrient. 6. 844-880: ISSN 20726643.

Kwan, Bonnie C.H. 2007. Lipoprotein Metabolism and Lipid Management in Chronic Kidney Disease. Journal of the American society of nephrology. 18: 1246-1261. 


\section{VOLUME 12 NOMOR 1 JUNI 2016}

Larsson, Karin, 2016. Formation of malondialdehyde (MDA), 4-hydroxy- 2hexenal (HHE) and 4-hydroxy-2-nonenal (HNE) in fish and fish oil during dynamic gastrointestinal in vitro digestion. Journal The Royal Society of Chemistry. DOI: 10.1039

Laurence, D.R., and A.L.,Bacharach., 1964, Evaluation of drug activities: pharmacometrics, 1th ed. Academic Press. London

Lorante, Leonardo, et al. 2015. Serum Malondialdehyde Levels in Patients with Malignant Middle Cerebral Artery Infarction Are Associated with Mortality. Plos One 10.1371.

Ma, Hongbao. 2006. Cholesterol and Human Health. The Journal of American Science. 2(1) : 4650.

Noori, S, et al. 2009. Effects Of Cocoa Powder On Oxidant/ Antioxidant Status In Liver, Heart And Kidney Tissuees Of Rats. The Journal of Animal and plant Sciences. Pages: 174-178 ISSN: 1018-7081.

Rasyid, HN et al. 2012. The Efficacy of Flavonoid Antioxidant from Chocolate Bean Extract: Prevention of Myocyte Damage Caused by Reperfusion Injury in Predominantly Anaerobic Sports. Malaysian Orthopaedic Journal. Vol 6. No. 3.

Tapas, AR. 2008. Flavonoids as Nutracenticals. Tropical Journal of Pharmaceutical Research. 7 (3): 1089-1099

Wignjosoesastro, Ccintyadewi. 2014. Pengaruh Bawang Putih (Allium Sativum) terhadap Pencegahan Hiperkolesterolemia Pada Tikus. Damianus Journal of Medicine. Vol. 13. No. 01.

Wijaya, andi, dkk. 2014. Aktivitas Antioksidan Sediaan Nanopartikel Kitosan Ekstrak Etanol Kelopak Rosela (Hibiscus Sabdariffa L) Pada Tikus Hiperkolesterol : Pengukuran Kadar Malondialdehid (Mda). Kartika Jurnal Ilmiah Farmasi. ISSN 2354-6565.

Winarsi. 2007. Bentuk Produk Oksidasi. In: Antioksidan Alami dan Radikal Bebas, Edisi 1, Kanisius. Yogyakarta.Pp.50-58

Zahrawardani, Diana, dkk. 2013. Analisis Faktor Risiko Kejadian Penyakit Jantung Koroner di RSUP Dr Kariadi Semarang. Jurnal Kedokteran Muhammadiyah. Vol. 1. No.2. 